\title{
HUBUNGAN ASUPAN MAKANAN DENGAN AKTIVITAS FISIK PADA PEKERJA BURUH BANGUNAN DI GAMPONG LAMBARO SKEP, BANDA ACEH
}

\author{
THE RELATIONSHIP BETWEEN FOOD INTAKE AND PHYSICAL \\ ACTIVITY ON CONSTRUCTION WORKERS IN GAMPONG LAMBARO \\ SKEP, BANDA ACEH
}

\author{
Indri Septiani Putr' ${ }^{1}$, Asiah ${ }^{2}$, Hafnati Rahmatan ${ }^{3}$, Safrida $^{4}$, Mimie Saputri ${ }^{5}$ \\ Program Studi Pendidikan Biologi Fakultas Keguruan dan Ilmu Pendidikan \\ Universitas Syiah Kuala, Banda Aceh \\ Email: indriseptianiputri4@gmail.com
}

\begin{abstract}
ABSTRAK
Penelitian bertujuan mengetahui adanya hubungan asupan makanan dengan aktivitas fisik pada pekerja buruh bangunan. Penelitian dilakukan bulan Januari 2020 berlokasi di Gampong Lambaro Skep, Banda Aceh dengan jenis penelitian survey dan observasi dengan desain cross sectional study. Parameter yang digunakan adalah hasil food recall 1×24 jam dan kuisioner aktivitas fisik. Data yang diperoleh selanjutnya di analisis dengan menggunakan analisis univariat yang dilanjutkan dengan uji korelasi dan uji t. Hasil analisis data diperoleh pada pekerja buruh bangunan $t_{\text {hit }}=3,200>t_{\text {tabel }}=2,063$. Hasil penelitian menunjukkan bahwa terdapat hubungan positif antara asupan makanan dengan aktivitas fisik pada pekerja buruh bangunan di Gampong Lambaro Skep, Banda Aceh dengan korelasi yang signifikan.
\end{abstract}

Kata Kunci: Asupan makanan, aktivitas fisik, korelasi

\section{ABSTRACT}

This study aimed at determining the relationship between food intake and physical activity on construction workers. It was conducted in January 2020 located in Gampong Lambaro Skep, Banda Aceh by using the type of survey research and observation with a cross-sectional study design. The parameters used were the result of a food recall $1 \times 24$ hours and a physical activity questionnaire. The data obtained were then analyzed by using univariate analysis followed by correlation test and t-test. The result of data analysis obtained on construction workers was thit $=3,200>$ ttable $=2,063$. The result showed that there was a possitive correlation between food intake and physical activity on construction workers in Gampong Lambaro Skep, Banda Aceh.

Keyword: Food intake, physical activity, correlation 


\section{PENDAHULUAN}

Pekerja memerlukan energi, gizi dan kalori yang sesuai dengan aktivitas fisik mereka saat bekerja (Sari, 2017). Menurut Eko,dkk (2010) asupan makanan pada tiap pekerja ibarat bensin bagi kendaraan.

Aktivitas fisik ialah gerakan yang dilakukan setiap orang dengan membutuhkan energi. Aktivitas fisik terbagi menjadi 3 kategori, diantaranya aktivitas fisik ringan, aktivitas fisik sedang, dan aktivitas fisik berat (Anggraini, 2014).

WHO menyebutkan, satu dari empat orang berusia dewasa kurang melakukan aktivitas fisik. Indonesia, tercatat sebanyak $26,1 \%$ penduduk yang termasuk kedalam kategori aktivitas fisik kurang (Abadini dkk, 2019).

Faktor utama untuk memenuhi kebutuhan gizi yaitu asupan makanan yang berfungsi sebagai sumber tenaga, sistem kekebalan tubuh dalam menghadapi serangan penyakit (Depatemen FKM UI, 2008). Asupan protein, lemak, dan karbohidrat yang dikonsumsi menjunjang kinerja para pekerja buruh.

Pola makan pekerja merupakan pengaturan jumlah makanan dan jenis makanan berdasarkan kebiasaan yang dikonsumsi setiap hari (Depdiknas, 2008). Secara garis besar rata-rata pekerja hanya sarapan sekedarnya dan langsung berangkat melaksanakan aktivitas sehari-hari. Mereka sering tidak memerhatikan asupan makanan yang sehat dan bergizi.

\section{METODE PENELITIAN}

\section{a. Tempat dan Waktu Penelitian}

Penelitian dilakukan pada bulan Januari 2021 berlokasi di Gampong Lambaro Skep, Banda Aceh.

\section{b. Pendekatan dan Jenis Penelitian}

Pendekatan yang digunakan yaitu pendekatan kuantitatif dengan jenis penelitian survey dan observasi.

\section{c. Populasi dan Sampel Penelitian}

Pekerja Buruh Bangunan menjadi populasi dalam penelitian ini, sampel penelitian adalah Gampong Lambaro Skep, Banda Aceh.

\section{d.Instrumen Penelitian}

Alat dalam penelitian yaitu kamera, kuesioner aktivitas fisik, food recall 1x24 jam, timbangan rumah tangga, dan alat tulis.

\section{e. Teknik Pengumpulan Data}

Penelitian ini mengumpulkan data dengan melakukan wawancara menggunakan food recall 1x24 jam untuk mengetahui jenis makanan dan banyaknya makanan yang dikonsumsi pada pekerja buruh bangunan, kemudian kuesioner aktivitas fisik berguna memperoleh data pekerja saat bekerja.

\section{f. Teknik Analisis Data}

Data analisis menggunakan rumus analisis univariat dilanjutkan uji korelasi 
dan uji t. Berikut adalah rumus yang digunakan :

1. Analisis Univariat

$$
\mathrm{P}=\frac{X}{N} \times 100 \%
$$

Keterangan :

$\mathrm{P} \quad=$ Presentasi

$\mathrm{X}=$ Jumlah responden

$\mathrm{N}=$ Jumlah total responden

(Usman, 2006)

2. Uji Korelasi

$$
r=\frac{n\left(\sum X Y\right)-\left(\sum X\right)\left(\sum Y\right)}{\sqrt{\left\{n \sum X^{2}-\left(\sum X\right)^{2}\right\}\left\{n \sum Y^{2}-\left(\sum Y\right)^{2}\right\}}}
$$

Keterangan:

$\mathrm{r} \quad=$ Koefisien korelasi

$\mathrm{X}=$ Variabel independen

$\mathrm{Y}=$ Variabel dependen

$\mathrm{n} \quad=$ Banyak sampel

Tabel 1. Interval Kelas Korelasi

\begin{tabular}{cc}
\hline Interval Korelasi & Tingkat Hubungan \\
\hline $0,00-0,199$ & Sangat rendah \\
$0,20-0,399$ & Rendah \\
$0,40-0,599$ & Sedang \\
$0,60-0,799$ & Kuat \\
$0,80-1,000$ & Sangat Kuat \\
\hline
\end{tabular}

(Suyono, 2018)

3. Uji t

$$
t=\frac{r \sqrt{\mathrm{n}-2}}{\sqrt{1-r^{2}}}
$$

Dengan taraf signifikan $\alpha=5 \%$ dan derajat bebas $(\mathrm{dk}=\mathrm{n}-2)$. Berdasarkan ketentuan jika $t_{\text {hitung }} \geq t_{\text {tabel }}$ bearti valid maka dari itu Ha diterima, jika sebaliknya $\mathrm{t}_{\text {hitung }}<\mathrm{t}_{\text {tabel }}$ bearti tidak valid, maka dari itu Ha ditolak.

(Usman, 2006)

\section{HASIL DAN PEMBAHASAN}

\begin{tabular}{ccc}
\hline \multicolumn{3}{c}{ Distribusi Frekuensi Sarapan Pagi } \\
\hline Kategori & Ln Sarapan & $\sum$ persen $(\%)$ \\
\hline Sarapan & 23 & $88 \%$ \\
Tidak Sarapan & 3 & $12 \%$ \\
\hline$\sum$ total & 26 & $100 \%$ \\
\hline
\end{tabular}

Tabel. 2 Hasil Analisis Univariat Distribusi Sarapan Pagi Pekerja Buruh.

Berikut hasil yang terdapat pada tabel 2 diperoleh data bahwa terdapat $88 \%$ sarapan pagi, dan $12 \%$ tidak sarapan pagi dari total 26 orang pekerja buruh;bangunan. Di simpulkan pekerja buruh; bangunan lebih

\begin{tabular}{|c|c|c|}
\hline \multicolumn{3}{|c|}{ Distribusi Frekuensi Aktivitas Fisik Pekerja Buruh } \\
\hline Aktivitas Fisik & $\sum \mathrm{n}$ & $\mathrm{n}(\%)$ \\
\hline Tinggi & 4 & $15 \%$ \\
\hline Sedang & 22 & $85 \%$ \\
\hline Rendă & 0 & $0 \%$ \\
\hline$\sum$ total & 26 & $100 \%$ \\
\hline
\end{tabular}
banyak bersarapan pagi daripada yang tidak bersarapan

Tabel. 3 Hasil Analisis Univariat Distribusi Frekuensi Hasil Skor Aktivitas Fisik

Berdasarkan tabel 3 diperoleh data skor aktivitas fisik responden pekerja buruh yaitu skor aktivitas fisik nilai sedang lebih dominan daripada skor aktivitas fisik

\begin{tabular}{|c|c|c|c|c|c|c|}
\hline \multirow{2}{*}{ Responden } & \multirow{2}{*}{$\begin{array}{c}\text { Asupan } \\
\text { Makanan }\end{array}$} & \multirow{2}{*}{$\begin{array}{c}\text { Aktivitas } \\
\text { Fisik }\end{array}$} & \multirow{2}{*}{ r } & \multirow{2}{*}{$\begin{array}{c}\text { Koefisien } \\
\text { Penentu } \\
\left(\mathrm{R}^{2}\right)\end{array}$} & \multicolumn{2}{|c|}{ Ujit } \\
\hline & & & & & $t_{\text {hitung }}$ & $t_{\text {tabel }}$ \\
\hline $\begin{array}{l}\text { Buruh Bangunan } \\
(26)\end{array}$ & 8415,9 & 942 & 0,546 & 0,2992 & 3,200 & 2,063 \\
\hline
\end{tabular}
tinggi, dan tidak ada satupun pekerja buruh; bangunan skor aktivitas fisik yang rendah.

Tabel. 4 Hubungan Asupan Makanan dengan Aktivitas Fisik pada Pekerja Buruh Bangunan di Gampong Lambaro Skep, Banda Aceh.

Berdasarkan tabel 4 hasil dengan uji korelasi person menunjukkan bahwa 
adanya hubungan antara asupan makanan dengan aktivitas fisik pada pekerja buruh dengan diperoleh hasil yaitu total 26 responden maka; $\mathrm{r}_{x y}=0,54$ pada interval korelasi 0,40 - 0,599 yang berarti memiliki korelasi yang sedang antara asupan makanan dengan aktivitas fisik pada pekerja buruh bangunan di Gampong Lambaro Skep, Banda Aceh. Kemudian dilakukan Uji t dan menunjukkan bahwa $t_{\text {hitung }}>\mathrm{t}_{\text {tabel }}$ maka hipotesis Ha diterima dengan tingkat korelasi yang signifikan.

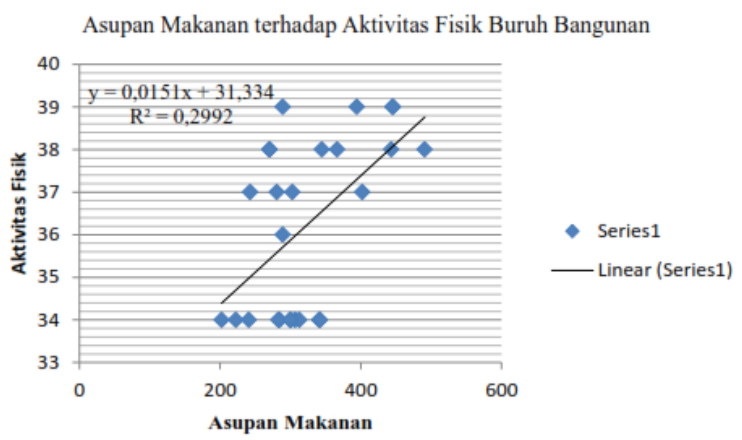

Gambar. 1 Kurva Korelasi Asupan Makanan terhadap Aktivitas Fisik pada Pekerja Buruh Bangunan.

Berdasarkan kurva di atas menunjukkan bahwa terdapat hubungan positif antara asupan makanan dengan aktivitas fisik pada pekerja buruh di Gampong Lambaro Skep, Banda Aceh. Maka semakin tinggi asupan makanan yang dikonsumsi, maka semakin tinggi aktivitas fisik.

\section{KESIMPULAN}

Simpulan yang didapatkan berdasarkan penelitian yaitu terdapat hubungan positif antara asupan makanan dengan aktivitas fisik pada pekerja buruh bangunan di Gampong Lambaro Skep, Banda Aceh dengan tingkat korelasi signifikan.

\section{DAFTAR PUSTAKA}

Abadini, D., C. E. Wuryaningsih. 2019. Determinan Aktivitas Fisik Orang Dewasa Pekerja Kantoran di Jakarta Tahun 2018. Jurnal Promosi Kesehatan Indonesia, 14(1), 15-28.

Anggraini, L. 2014. Hubungan Tingkat Aktivitas fisik terhadap Status Gizi pada Anak Usia Prasekolah. Skripsi. Universitas Diponegoro.

Departemen FKM UI. 2008. Gizi dan Kesehatan. Jakarta: PT. Raja Grafindo Persada.

Depdiknas. 2008. Kamus Besar Bahasa Indonesia. Jakarta: Pusat Bahasa.

Eko, H. A., \& Dina, N. A. N. 2010. Hubungan Antara Tingkat Kesegaran Jasmani dan Status Gizi dengan Produktivitas Kerja. Jurnal Kesehatan Masyarakat. 5(2), 145150.

Sari, A. R., \& Muniroh, L. 2017. Hubungan Kecukupan Asupan Energi dan Status Gizi dengan Tingkat Kelelahan Kerja Pekerja Bagian Produksi (Studi di PT. Multi Aneka Pangan Nusantara Surabaya). Jurnal DOI, 5(1): 275281.

Suyono. 2018. Analisis Regresi untuk Penelitian. Yogyakarta: Deepublish.

Usman, H., \& P. S. Akbar. 2006. Pengantar Statistik. Jakarta: PT. Bumi Aksara. 